\title{
Zinc Recovery through Electrolytic Refinement Using Insoluble Ir + Sn + Ta + PdOx/Ti Cathode to Reduce Electrical Energy Use
}

\author{
Ji-Hyun Kim, Jung Eun Park and Eun Sil Lee * \\ Center for Plant Engineering, Institute for Advanced Engineering, Yongin-si 17180, Korea \\ * Correspondence: les0302@iae.re.kr; Tel.: +82-31-330-7209
}

Received: 30 July 2019; Accepted: 25 August 2019; Published: 29 August 2019

check for updates

\begin{abstract}
In this study, an alumina ( $\mathrm{Al}$ ) anode, a lead cathode, and insoluble catalytic cathodes ( $\mathrm{IrOx}, \mathrm{PdOx}, \mathrm{TaOx}$, and $\mathrm{SnOx}$ ) were used as electrodes to enhance zinc recovery. The traditionally used iron electrode and insoluble catalytic electrodes were also used to compare the recovery yield when different types of electrodes were subjected to the same amount of energy. The lead electrode showed over $5000 \Omega$ higher electrode resistance than did the insoluble catalytic electrode, leading to overpotential requiring higher electrical energy. As electrical energy used by the lead and the insoluble catalytic electrodes were 2498.97 and $2262.37 \mathrm{kwh} / \mathrm{ton}-\mathrm{Zn}$, respectively, electrical energy can be reduced by $10 \%$ when using an insoluble catalytic electrode compared to that when using a lead electrode. Using recovery time (1-4 h) and current density $\left(100-500 \mathrm{~A} / \mathrm{m}^{2}\right)$ as variables, the activation, concentration polarization, and electrode resistance were measured for each condition to find the optimum condition for zinc recovery. A recovery yield of about $77 \%$ was obtained for up to $3 \mathrm{~h}$ of zinc recovery time at a current density of $200 \mathrm{~A} / \mathrm{m}^{2}$, which is lower than that (about $80 \%$ ) obtained at $300 \mathrm{~A} / \mathrm{m}^{2}$. After $3 \mathrm{~h}$ of recovery time, electrode resistance ( $\mathrm{Zn}$ concentration reduction, hydrogen generation on electrode surface) and overpotential increase with time decreased at a current density of $200 \mathrm{~A} / \mathrm{m}^{2}$, leading to a significant increase in zinc recovery yield $(95 \%)$.
\end{abstract}

Keywords: zinc recovery; insoluble catalytic electrode; electrical energy; recovery time; current density; activation polarization; current resistance

\section{Introduction}

The zinc smelting process, urban mining, and plating industries produce zinc solutions containing various impurities $(\mathrm{F}, \mathrm{Cl}, \mathrm{Mn}, \mathrm{As}, \mathrm{Mg}$, and $\mathrm{Ca}$ ); however, methods to recover high-purity zinc from these solutions are actively being researched [1]. The most commonly used method involves solvent extraction, through which zinc solution and impurities are separated to produce a zinc electrolyte with high purity and high concentration. Afterward, the electrolyte is subjected to electrolyte refinement to recover high-purity zinc metal [2-6]. During electrolyte refinement, the electricity cost accounts for $50-80 \%$ of the production cost and is the main factor that reduces the economic feasibility of the zinc recovery process. High electric power is required for the use of lead $(\mathrm{Pb})$ plates as electrodes during zinc recovery. Limitations of lead electrodes require a high overpotential, which contributes to the high electric cost and produces precipitates due to the low erosion resistance, thus reducing the electrode lifespan [7].

Titanium (Ti) electrodes with high erosion resistance and conductivity are, therefore, being used instead of lead electrodes; in particular, electrodes made of titanium plate with various insoluble catalyst coatings are being developed [8]. Insoluble catalysts include $\mathrm{IrOx}, \mathrm{PdOx}, \mathrm{TaOx}$, and $\mathrm{SnOx}$, where $\mathrm{IrOx}$ and $\mathrm{PdOx}$ are used as activators to improve the current efficiency, while $\mathrm{TaOx}$ and $\mathrm{SnOx}$ are 
used as a stabilizer and dispersant, respectively, to increase the electrode's lifespan [9-13]. For example, in a $\mathrm{IrOx} / \mathrm{Ti}$ electrode, $\mathrm{Mn}$ in the electrolyte is electrodeposited in an oxide form at the cathode surface to increase cell resistance, while F ions corrode the coated catalyst at the cathode surface, critically reducing the electrode efficiency and lifespan [14]. To improve the electrodes, $\mathrm{TaOx}-\mathrm{SnOx}-\mathrm{PdOx}$ oxides can be added as the main catalysts for the IrOx electrode to increase the electrode's lifespan and current efficiency compared to an IrOx/Ti electrode [14].

Design factors for the zinc recovery process include the zinc purity, cathode cell voltage, electrical energy, $\mathrm{pH}$, current density, zinc concentration, recovery temperature, and electrode spacing. Regarding the $\mathrm{pH}$ factor, a zinc solution was prepared using zinc oxide and sulfuric acid, and the zinc concentration was reported to be different depending on the $\mathrm{pH}$. The reaction scheme of the reaction is as follows (Equation (1)):

$$
\mathrm{ZnO}+\mathrm{H}_{2} \mathrm{SO}_{4} \rightarrow \mathrm{ZnSO}_{4}+\mathrm{H}_{2} \mathrm{O} .
$$

Pearson et al. (1981) showed zinc leaching concentrations according to the $\mathrm{pH}$ in industrial dust containing zinc by using the EAFD method. When the $\mathrm{pH}$ was 2, zinc was recovered to $85 \%-90 \%$, and the zinc recovery was reduced by $80 \%$ as the $\mathrm{pH}$ was increased to 3-4 [15]. By lowering the $\mathrm{pH}$, a high concentration of zinc solution could be produced. In addition, the current density, zinc concentration, recovery temperature, electrode spacing, etc. were known to promote zinc recovery by improving $\mathrm{Zn}$ ion transfer [15].

In this study, therefore, an alumina (Al) anode, a lead cathode, and insoluble catalytic cathodes, which can increase electrode stability and conductivity, were used to develop electrodes. By comparing the electrodes with the lead electrode conventionally used in zinc recovery and insoluble catalytic electrodes, the increase in recovery yield was identified for the given energy. Furthermore, the recovery time and current density of insoluble catalytic electrodes were used as variables to measure activation, concentration polarization, and electrode resistance in order to find the optimum condition for zinc recovery.

\section{Materials and Experimental Methods}

\subsection{Materials}

For the lead electrode, lead plate (thickness: $1.0 \mathrm{~mm}$, manufacturer: Metal Power) was purchased and cut into an electrode surface area of $100 \mathrm{~mm}^{2}$. The three- and four-component electrodes were purchased from Wesco Electrode. The Ti plate (thickness: $2.0 \mathrm{~mm}$ ) was used and coated with three components (Ir + Sn + TaOx/Ti, IrOx:SnOx:TaOx $=45: 45: 10, \mathrm{wt} \%)$ and four components $(\mathrm{Ir}+\mathrm{Sn}+\mathrm{Ta}+$ $\mathrm{PdOx} / \mathrm{Ti}, \mathrm{PdOx}=8-12, \mathrm{wt} \%$ ) with a $20 \mu \mathrm{m}$ thickness [14]. Electrolyte containing zinc ions was produced using sulfuric acid $\left(\mathrm{H}_{2} \mathrm{SO}_{4}\right.$, manufacturer: Samchun, Seoul, republic of Korea purity: $\left.95 \%\right)$ and zinc oxide ( $\mathrm{ZnO}$, manufacturer: Sigma-Aldrich, St. Louis, MO, USA purity: 99.9\%). The composition of the solvent extract solution was $(\mathrm{Zn}-116.73 \mathrm{~g} / \mathrm{L}, \mathrm{Na}-0.43 \mathrm{~g} / \mathrm{L}, \mathrm{Mn}-0.41 \mathrm{~g} / \mathrm{L}$, and S-75.59 g/L).

\subsection{Measurement Methods}

The content of the coating material of the insoluble catalyst electrode was analyzed using scanning electron microscopy with energy dispersive X-ray spectroscopy (SEM/EDX) (model: Inspect F50, manufacturer: ThermoFisher, Hillsboro, OR, USA). Zinc recovery was measured with the Galvanic measurement method, using a multi-channel electrochemical measurement device (model: ZIVE BP2, manufacturer: WonATech, Seoul, Korea) by applying a certain amount of current to recover zinc in the anode. The Galvanic measurement method was used in the condition where the Al electrode was the anode and lead or an insoluble catalytic electrode was the cathode with the same electrode surface area $\left(100 \mathrm{~mm}^{2}\right)$. In this study, the conditions used were electric currents of various intensities $(0.1-0.5 \mathrm{~A})$, recovery time from 1 to $4 \mathrm{~h}$, sulfuric acid concentrations of $3 \mathrm{M}$, zinc concentrations of $100 \mathrm{~g}-\mathrm{Zn} / \mathrm{L}-3 \mathrm{M}$ $\mathrm{H}_{2} \mathrm{SO}_{4}$, electrode distance of $3 \mathrm{~cm}$, electrolyte of $2 \mathrm{~L}$, solution temperature of $40^{\circ} \mathrm{C}$, and stirring speed of $150 \mathrm{rpm}$. Polarization and resistance measurements were conducted using three-electrode systems 
with $\mathrm{Ag} / \mathrm{AgCl}$ as the standard electrode, where a Pt electrode was the anode and a lead or an insoluble catalytic electrode was the cathode in sulfuric acid ( $3 \mathrm{M}$ ) and zinc concentration (100 g-Zn/L-3 M $\mathrm{H}_{2} \mathrm{SO}_{4}$ ) conditions. Activation and concentration polarization were measured by the potential sweep method. The measured values were converted to the log scale and then converted to a Tafel plot [16]. Electrode resistance was measured by the electrochemical impedance spectroscopy (EIS) method, and the modeling of the resistance circuit was conducted by the ZIVE ZMAN (EIS data analysis software) program.

\section{Results and Discussion}

\subsection{Analysis of the Elecments Included in Electrode Composition}

SEM and EDX analysis results of three-component $(\mathrm{Ir}+\mathrm{Sn}+\mathrm{TaOx} / \mathrm{Ti})$ and four-component $(\mathrm{Ir}+\mathrm{Sn}+\mathrm{Ta}+\mathrm{PdOx} / \mathrm{Ti})$ insoluble catalyst electrodes are shown in Figure 1 . The cross-section of the electrode coated with an insoluble catalyst material on the Ti substrate was measured by SEM and the catalyst component was analyzed using EDX, specifying a partial area of the coating material. Through the EDX qualitative analysis, it was confirmed that all of the elements included in the three-component and four-component systems were detected.
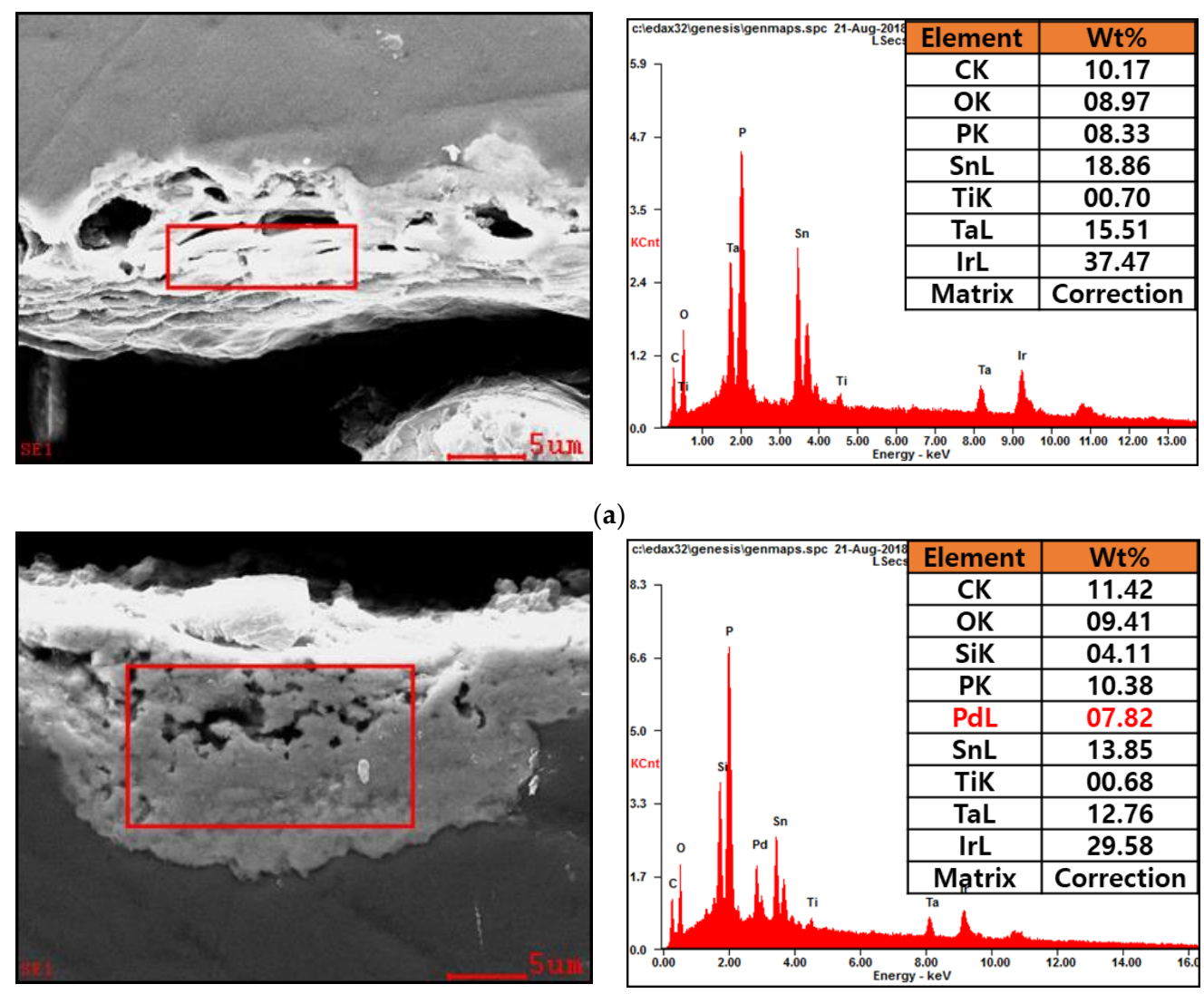

(b)

Figure 1. SEM and EDX analysis of $\mathrm{Ir}+\mathrm{Sn}+\mathrm{TaOx} / \mathrm{Ti}(\mathbf{a})$ and $\mathrm{Ir}+\mathrm{Sn}+\mathrm{Ta}+\mathrm{PdOx} / \mathrm{Ti}(\mathbf{b})$.

\subsection{Overpotential and Electrode Resistance according to Electrode Composition}

Activation polarization and concentration polarization of the lead, $\mathrm{Ir}+\mathrm{Sn}+\mathrm{TaOx} / \mathrm{Ti}$ (three-component), and $\mathrm{Ir}+\mathrm{Sn}+\mathrm{Ta}+\mathrm{PdOx} / \mathrm{Ti}$ (four-component) electrodes were calculated using the Tafel plot, as shown in Table 1. In the voltage-current relationship graph, the oxidation-reduction current interval appears. By logging the reduction current, a graph of the Tafel plot is obtained. When the applied current is low, it is greatly influenced by the electrode material; however, it is affected by 
the electrolyte concentration as the applied current is increased. As a result, the activation polarization according to the electrode material reactivity appears in the low applied current portion, while the concentration polarization according to the lower electrolyte concentration in the high applied current portion. Therefore, since activation and concentration polarization sections are divided according to the Tafel slope, the activation and concentration polarization values can be indirectly checked by checking the voltage of the sections (Figure 2) [16].

Table 1. Overpotential and electrode resistance by electrode components.

\begin{tabular}{ccccccc}
\hline Sample & $\begin{array}{c}\text { Solution } \\
\text { Condition }\end{array}$ & $\begin{array}{c}\text { Activation } \\
\text { Polarization } \\
\left(\eta_{\mathbf{a}}\right)\end{array}$ & $\begin{array}{c}\text { Concentration } \\
\text { Polarization } \\
\left(\eta_{\mathbf{c}}\right)\end{array}$ & $\begin{array}{c}\text { Activation }+ \\
\text { Concentration } \\
\text { Polarization } \\
(\boldsymbol{\eta})\end{array}$ & $\begin{array}{c}\text { Electrode } \\
\text { Resistance } \\
(\mathbf{R c t}, \boldsymbol{\Omega})\end{array}$ & $\begin{array}{c}\text { Solution } \\
\text { Conductivity } \\
\text { at 25 }{ }^{\circ} \mathbf{C} \\
(\mathbf{m S} / \mathbf{c m})\end{array}$ \\
\hline $\mathbf{P b}$ & Sulfuric & 0.09 & 0.40 & 0.49 & 5902.00 & \\
$\mathbf{I r}+\mathbf{S n}+\mathbf{T a}$ & $\mathbf{a c i d}-\mathbf{3} \mathbf{M}$, & 0.04 & 1.16 & 1.20 & 0.98 & 405.20 \\
$\mathbf{I r}+\mathbf{S n}+\mathbf{T a}+\mathbf{P d}$ & $\mathbf{Z n - 1 0 0 ~ g / L ~}$ & 0.03 & 1.10 & 1.13 & 0.02 & \\
\hline
\end{tabular}

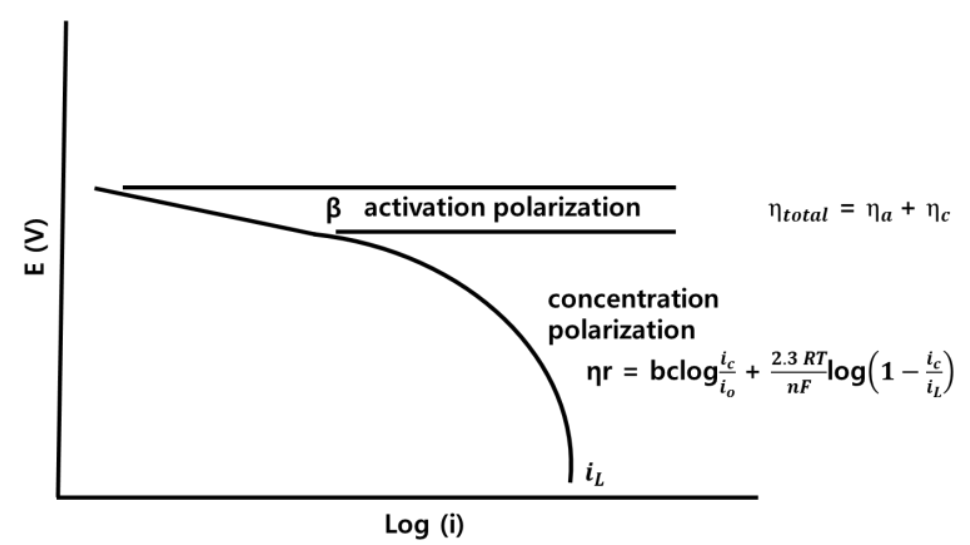

Figure 2. Tafel plot of activation and concentration polarization.

Activation polarization reflects an overpotential of charge transfer, which is more active when the activation polarization is low. The ion concentration is, therefore, greatly reduced locally, which in turn significantly increases the concentration polarization [16]. The activation polarization values of the lead, $\mathrm{Ir}+\mathrm{Sn}+\mathrm{TaOx} / \mathrm{Ti}$ (three-component), and $\mathrm{Ir}+\mathrm{Sn}+\mathrm{Ta}+\mathrm{PdOx} / \mathrm{Ti}$ (four-component) electrodes were $0.09,0.04$, and $0.03 \eta_{a}$, respectively. IrOx improves the adhesive ability of coating materials on the Ti plate electrode, while PdOx is known to enhance the activation sites. The $\mathrm{Ir}+\mathrm{Sn}+\mathrm{TaOx} / \mathrm{Ti}$ (three-component) and $\mathrm{Ir}+\mathrm{Sn}+\mathrm{Ta}+\mathrm{PdOx} / \mathrm{Ti}$ (four-component) electrodes showed a lower activation polarization by approximately $0.05 \eta_{\mathrm{a}}$. The concentration polarization values of the lead, $\mathrm{Ir}+\mathrm{Sn}+$ $\mathrm{TaOx} / \mathrm{Ti}$ (three-component), and $\mathrm{Ir}+\mathrm{Sn}+\mathrm{Ta}+\mathrm{PdOx} / \mathrm{Ti}$ (four-component) electrodes were 0.40, 1.16, and $1.10 \eta_{c}$, respectively. The latter two electrodes with a lower activation polarization showed higher concentration polarization values than that of the lead $(\mathrm{Pb})$ electrode.

The overpotential of the electrode is sum of the activation polarization and concentration polarization,

$$
\eta=\eta_{\mathrm{a}}+\eta_{\mathrm{c}}
$$

According to the aforementioned results, the overpotential values of the lead, three-component, and four-component electrodes were calculated as $0.49,1.20$, and $1.13 \eta$, respectively, indicating that the overpotential is greatly affected by the concentration polarization. A higher concentration polarization increased the rate of reduction of reactants [16], and thus zinc recovery was more active in the threeand four-component electrode systems compared to that in the lead electrode system.

Electrode resistance in lead was measured using the EIS method, as shown in Figure 3. The circuit diagram used in the resistance measurement is shown below, in which Rs is the solution resistance, 
Rct is the electrode resistance, $\mathrm{W}$ is the diffusion resistance, and $\mathrm{Q}$ is used in cases of a non-uniform electrode surface, instead of capacity (C).

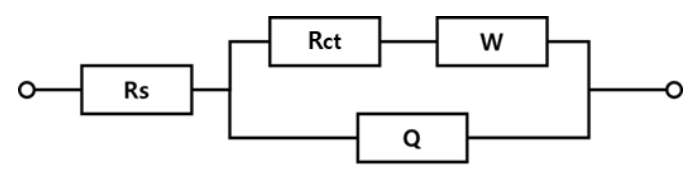

(a)

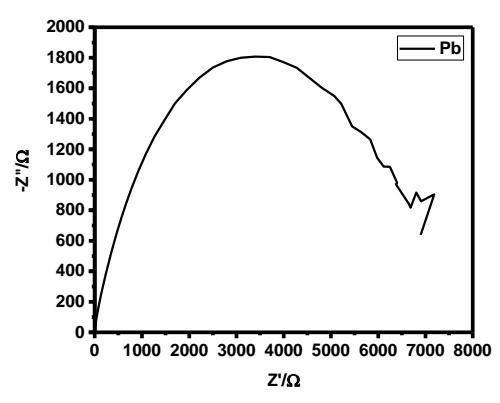

(b)

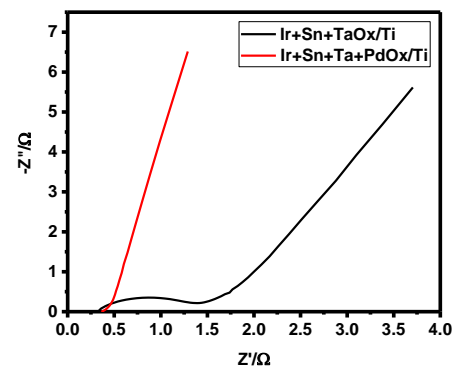

(c)

Figure 3. Circuit diagram used in resistance measurement (a), Nyquist plot of $\mathrm{Pb}(\mathbf{b})$, and that $\mathrm{Ir}+\mathrm{Sn}+$ $\mathrm{TaOx} / \mathrm{Ti}$ and $\mathrm{Ir}+\mathrm{Sn}+\mathrm{Ta}+\mathrm{PdOx} / \mathrm{Ti}$ electrodes $(\mathbf{c})$.

Electrode resistance values, measured using the above resistance measurement circuit (Figure 3) of the lead, three-, and four-component electrodes were 5902.00, 0.98, and 0.02, respectively. The threeand four-component electrodes with $\mathrm{IrOx}$ and $\mathrm{PdOx}$ showed lower electrode resistance values than did the lead electrode (Table 1).

\subsection{Comparative Evaluation of Recovery Yield according to Electrode Components}

Metal zinc recovery using the lead, $\mathrm{Ir}+\mathrm{Sn}+\mathrm{TaOx} / \mathrm{Ti}$ (three-component), and $\mathrm{Ir}+\mathrm{Sn}+\mathrm{Ta}+$ $\mathrm{PdOx} / \mathrm{Ti}$ (four-component) electrodes was conducted by subjecting the reactants to a current so as to reduce zinc at the anode. Zinc recovery was conducted at various current densities (100, 200, 300, 400 , and $500 \mathrm{~A} / \mathrm{m}^{2}$ ) and the average voltage was identified for the given current density (Figure 4a). An increase in current density led to a greater increase in the average voltage in electrodes with a higher overpotential, and the slope values for the $\mathrm{Pb}$, three-component, and four-component electrodes were $0.0006,0.0014$, and 0.0007 , respectively. The changes in the slope for the three-component electrode increased rapidly after $200 \mathrm{~A} / \mathrm{m}^{2}$, while the four-component electrode had a high overpotential of 1.13. Thus, the zinc recovery reaction occurs actively in the four-component electrode; however, its initial voltage is the lowest $(2.48 \mathrm{~V})$, while the change in the slope for the average voltage with the current density is not high. The four-component electrode is therefore the most suitable electrode to reduce the use of electrical energy. 


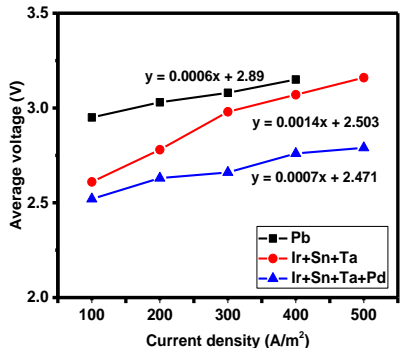

(a)

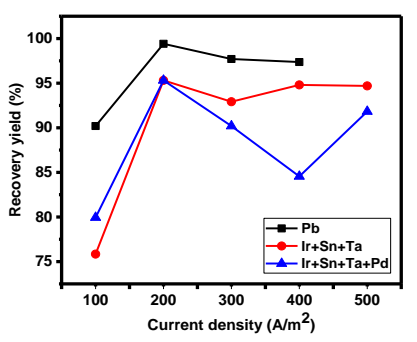

(b)

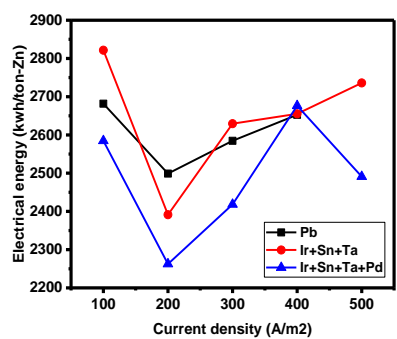

(c)

Figure 4. Average voltage (a), recovery yield (b), and electrical energy (c) by current density.

The results of the zinc recovery yield according to the current density (Figure $4 \mathrm{~b}$ ) showed the highest yields in the lead and in the three- and four-component electrodes when the current density was $200 \mathrm{~A} / \mathrm{m}^{2}$ and the recovery time was fixed at $4 \mathrm{~h}$. The recovery yields were $99.41,95.31$, and $95.31 \%$, respectively. As shown in the Galvanic measurement graph (Figure 5), when the initial voltage was low and the current density was $200 \mathrm{~A} / \mathrm{m}^{2}$, after $3 \mathrm{~h}$ of recovery time the voltage increase was not significant in the four-component electrode (Figure 5c). Increasing the current density to over $200 \mathrm{~A} / \mathrm{m}^{2}$ led to a significant increase in the initial voltage due to the significant increase in ion etching caused by the increase in current density, as well as a significant increase in the concentration polarization due to the reduction of the local ion concentration. The electrical energy graph associated with the current density also showed the lowest energy when the current density was $200 \mathrm{~A} / \mathrm{m}^{2}$.

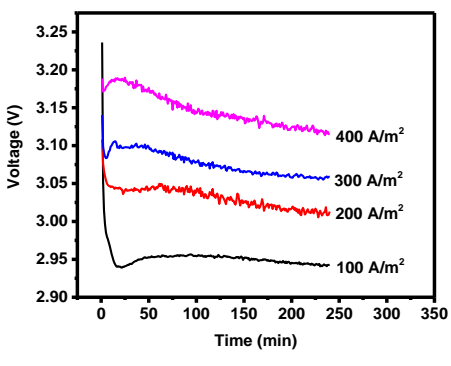

(a)

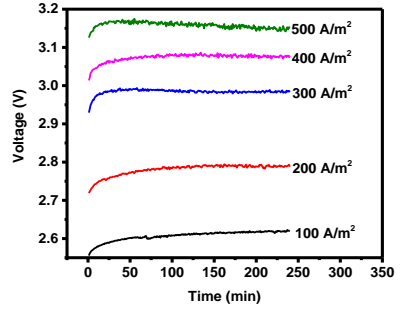

(b)

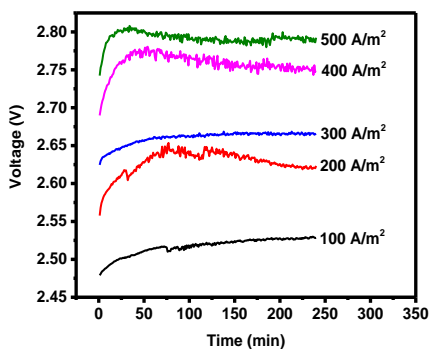

(c)

Figure 5. Galvanic graph for $\mathrm{Pd}(\mathbf{a}), \mathrm{Ir}+\mathrm{Sn}+\mathrm{TaOx} / \mathrm{Ti}(\mathbf{b})$, and $\mathrm{Ir}+\mathrm{Sn}+\mathrm{Ta}+\mathrm{PdOx} / \mathrm{Ti}(\mathbf{c})$.

The theoretical amount of zinc recovery $(\mathrm{g})$ can be calculated as below. This formula calculates the amount of recovered zinc by the electrochemical reaction according to the input current (Equation (3)):

$$
\begin{aligned}
& \text { Theoretical amount of zinc recovery }(\mathrm{g})=\frac{\mathrm{Zn}{ }^{2+} \operatorname{mol}(\mathrm{mol}) \times \mathrm{Zn} \text { atomic weight }(\mathrm{g} / \mathrm{mol})}{\mathrm{Zn}^{2+} \text { equivalent number }}, \\
& \qquad \mathrm{Zn2^{+ }} \operatorname{mol}(\mathrm{mol})=\frac{\mathrm{Zn} \text { current }(\mathrm{A}) \times \mathrm{Time}(\mathrm{h})}{\text { Faraday constant }(\mathrm{C} / \mathrm{mol})} .
\end{aligned}
$$

Electrical energy (kwh/ton-Zn) is the amount of energy required to recover zinc (Equation (5)):

$$
\text { Electrical energy }(k w h / \text { ton }-Z n)=\frac{Z n \text { current }(A) \times \text { Average voltage }(v) \times \text { Time }(h) \times 1000}{Z n \text { weight }(\text { ton })} \text {. }
$$

On the other hand, lead electrodes are known to have high oxidation reactivity, and thus zinc recovery at the alumina (anode) is efficient. The lead electrode, however, had a high electrode resistance 
of over $5000 \Omega$ compared to the three- and four-component electrodes, causing overpotential, which in turn leads to high electrical energy use. Consequently, at the same current density $\left(200 \mathrm{~A} / \mathrm{m}^{2}\right)$, the amounts of electrical energy used by the lead, three-component, and four-component electrodes were $2498.97,2391.40$, and $2262.37 \mathrm{kwh} / \mathrm{ton}-\mathrm{Zn}$, respectively (Figure 4c). The use of the four-component electrode can reduce the electrical energy use by $10 \%$ compared to the amount required when using the lead electrode. Furthermore, insoluble electrodes cannot precipitate due to the presence of impurities in the electrolyte, further increasing the amount of electrical energy reduction when solvent extracts are used as electrolytes. Moreover, when zinc recovery using solvent extraction was conducted at the recovery condition (four-component electrode (cathode) and alumina (anode) as electrodes; current density: $500 \mathrm{~A} / \mathrm{m}^{2}$; recovery time: $4 \mathrm{~h}$ ), the electrical energy used by the four-component electrode was $2280.32 \mathrm{kwh} / \mathrm{ton}-\mathrm{Zn}$, corresponding to an approximately $19 \%$ decrease when compared to the lead electrode. Zinc recovery using a lead electrode leads to a reaction with impurities in electrolytes, which in turn results in precipitation to electrolytes, and such a electrochemical reaction with impurities has been observed to significantly reduce the yield. Although insoluble catalyst electrodes have an expensive disadvantage compared to $\mathrm{Pb}$, the reason why they should be developed is that existing electrodes have a short lifespan of 1-2 years or less, while insoluble catalyst electrodes have a long lifespan of more than 5 years [14]. Moreover, in the actual electrolyte solution containing many impurities, the energy reduction was found to be $20 \%$ or more as compared with that in the $\mathrm{Pb}$ electrode.

\subsection{Optimization of Zinc Recovery Condition according to Recovery Time and Current Density}

The activation, concentration polarization, electrode resistance, and recovery yield were measured by recovery time (1-4h) of the four-component electrode, as shown in Table 2 . The Figure $4 \mathrm{c}$ graph shows that the initial voltage of zinc recovery significantly increased at a current density of $200 \mathrm{~A} / \mathrm{m}^{2}$, followed by a decrease in the voltage. Many factors increase the voltage, especially resistance and polarization. In Figure 6, zinc recovery yield is shown to be proportional to changes in the voltage. The initial recovery yield was low, about $79 \%$, followed by an increase to about $95 \%$ after $3 \mathrm{~h}$. This phenomenon was investigated through identifying the cause of the recovery yield increase by measuring activation, concentration polarization, and electrode resistance with the increase of the recovery time (Table 2).

Table 2. Overpotential and electrode resistance in the four-component electrode according to recovery time.

\begin{tabular}{|c|c|c|c|c|c|c|c|}
\hline Sample & $\begin{array}{c}\text { Current } \\
\text { Density } \\
\left(\mathrm{A} / \mathrm{m}^{2}\right)\end{array}$ & $\begin{array}{l}\text { Recovery } \\
\text { Time } \\
\text { (h) }\end{array}$ & $\begin{array}{l}\text { Activation } \\
\text { Polarization } \\
\qquad\left(\eta_{\mathrm{a}}\right)\end{array}$ & $\begin{array}{c}\text { Concentration } \\
\text { Polarization } \\
\left(\eta_{c}\right)\end{array}$ & $\begin{array}{c}\text { Activation }+ \\
\text { Concentration } \\
\text { Polarization } \\
(\eta)\end{array}$ & $\begin{array}{c}\text { Electrode } \\
\text { Resistance } \\
(\text { Rct, } \Omega)\end{array}$ & $\begin{array}{l}\text { Solution } \\
\text { Conductivity } \\
\text { at } 25^{\circ} \mathrm{C} \\
(\mathrm{mS} / \mathrm{cm})\end{array}$ \\
\hline \multirow{7}{*}{$\mathrm{Ir}+\mathrm{Sn}+\mathrm{Ta}+\mathrm{Pd}$} & \multirow{5}{*}{200} & 0 & 0.03 & 1.10 & 1.13 & 0.02 & 446.30 \\
\hline & & 1 & 0.10 & 1.30 & 1.40 & 0.03 & 422.70 \\
\hline & & 2 & 0.08 & 1.29 & 1.37 & 0.06 & 394.10 \\
\hline & & 3 & 0.10 & 1.30 & 1.40 & 0.24 & 411.70 \\
\hline & & 4 & 0.11 & 1.29 & 1.40 & 0.25 & 409.20 \\
\hline & \multirow{2}{*}{300} & 1 & 0.11 & 1.28 & 1.39 & 0.11 & 416.40 \\
\hline & & 2 & 0.10 & 1.29 & 1.39 & 0.13 & 373.30 \\
\hline
\end{tabular}




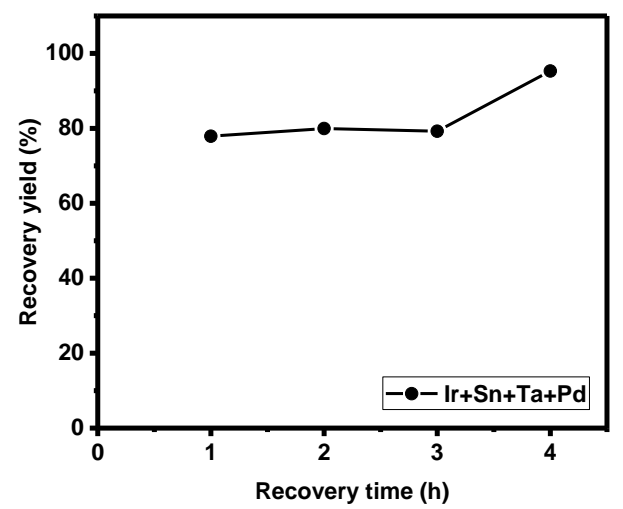

(a)

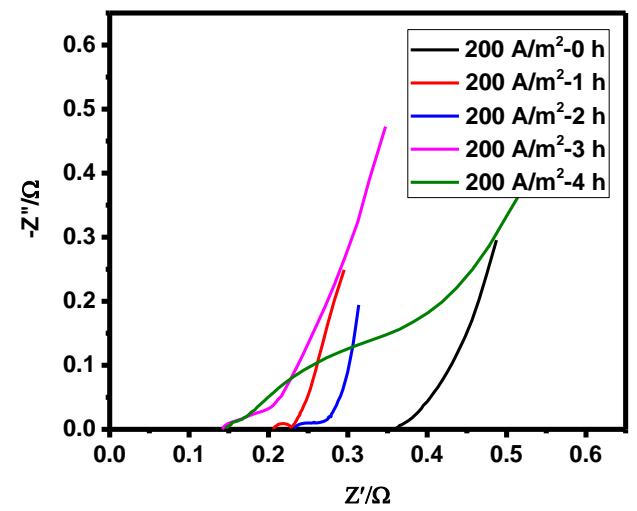

(b)

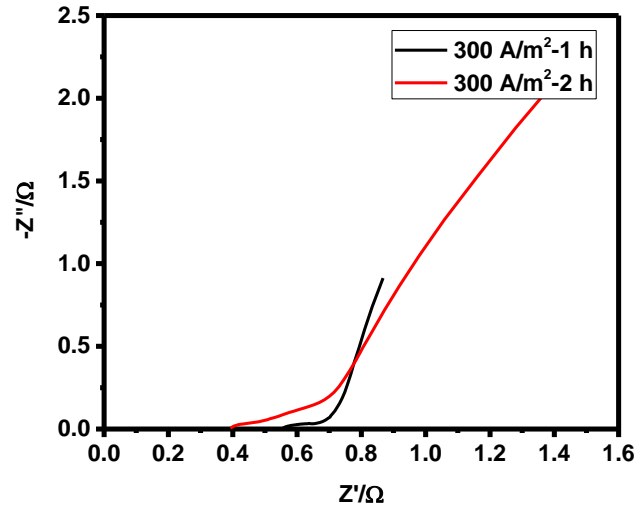

(c)

Figure 6. Recovery yield in the four-component electrode according to recovery time (a), Nyquist plot of $\mathrm{Ir}+\mathrm{Sn}+\mathrm{Ta}+\mathrm{PdOx} / \mathrm{Ti}$ at a current density of $200 \mathrm{~A} / \mathrm{m}^{2}$ according to recovery time $(0-4 \mathrm{~h})(\mathbf{b})$, and at a current density of $300 \mathrm{~A} / \mathrm{m}^{2}$ according to recovery time (1-2 h) (c).

During the initial $1 \mathrm{~h}$ of zinc recovery, the activation and concentration polarization significantly increased. This is attributed to the effect of crystallization polarization ( $\left.\eta_{\text {crystal }}\right)$, which occurs during the initial recovery of metal zinc at alumina (anode). The activation polarization significantly increased from 0.03 (initial) to $0.10 \eta_{\mathrm{a}}$ during the first hour, followed by a decrease to $0.08-0.11 \eta_{\mathrm{a}}$, and then a gradual increase. The increase in recovery time contributed to the increase of theactivation polarization from 0.03 to $0.11 \eta_{a}$, while the electrode resistance continuously increased from 0.02 to $0.25 \Omega$. With increasing zinc recovery, the activation and concentration polarization related to zinc recovery reactivity did not significantly increase; however, the electrode resistance increased due to the reduction in active surface area for the anode.

The recovery yield was therefore not significantly reduced according to recovery time, and the recovery yield increased to $95 \%$ after $3 \mathrm{~h}$ (Figure 6).

The results of the zinc recovery yield according to the current density are shown in Figure $4 \mathrm{~b}$. Zinc recovery was the highest at $200 \mathrm{~A} / \mathrm{m}^{2}$, and the yield decreased with a further increase in the current density. To identify the phenomenon responsible for this result, the electrode resistance, activation, and concertation polarization were measured in the four-component electrode while increasing the current density for the initial hour. The results show that the highest recovery yield was obtained at a current density of $300 \mathrm{~A} / \mathrm{m}^{2}$, and that the recovery yield decreased with the increase of the current density. A current density of $300 \mathrm{~A} / \mathrm{m}^{2}$ (initial voltage: $2.62 \mathrm{~V}$ ) increased the current flow, leading to a higher current density recovery rate compared to that obtained at $200 \mathrm{~A} / \mathrm{m}^{2}$ (initial voltage: $2.56 \mathrm{~V}$ ). 
The scenario with increased recovery yield had a lower overpotential and smaller increase in activation polarization and electrode resistance, and the zinc recovery on the electrode surface was found to be optimum. There was thus hardly any increase in the initial overpotential during $3 \mathrm{~h}$ of zinc recovery in the optimum condition. Although a high current density of $300 \mathrm{~A} / \mathrm{m}^{2}$ with a higher exerted current is effective, the increase in the electrode resistance decreased after $3 \mathrm{~h}$ of recovery time. The increase in the zinc recovery yield was higher at a current density of $200 \mathrm{~A} / \mathrm{m}^{2}$ with less change in overpotential (Figure 7a and Table 3).

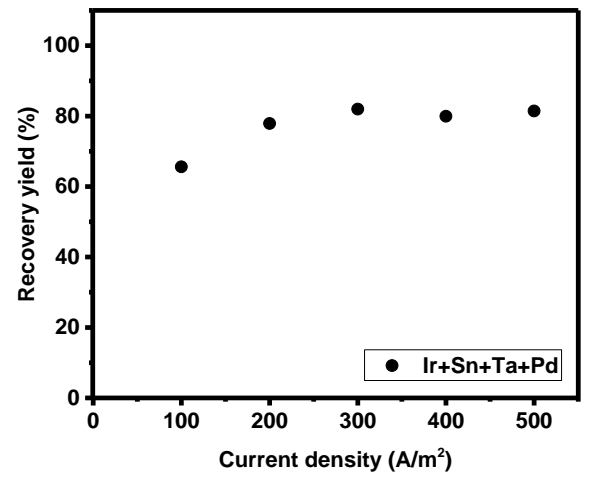

(a)

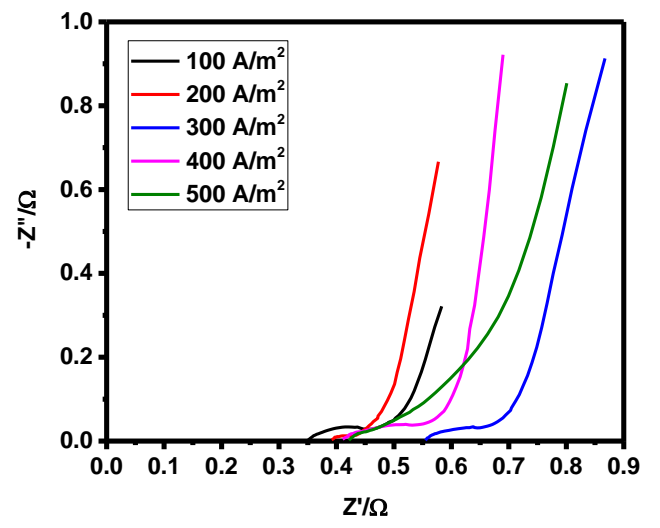

(b)

Figure 7. Recovery yield in the four-component electrode according to current density (a), and Nyquist plot of $\mathrm{Ir}+\mathrm{Sn}+\mathrm{Ta}+\mathrm{PdOx} / \mathrm{Ti}$ according to current density $\left(0-500 \mathrm{~A} / \mathrm{m}^{2}\right)(\mathbf{b})$.

Table 3. Overpotential and electrode resistance in the four-component electrode according to current density.

\begin{tabular}{|c|c|c|c|c|c|c|}
\hline Sample & $\begin{array}{c}\text { Current } \\
\text { Density } \\
\left(\mathrm{A} / \mathrm{m}^{2}\right)\end{array}$ & $\begin{array}{c}\text { Activation } \\
\text { Polarization } \\
\left(\eta_{\mathrm{a}}\right)\end{array}$ & $\begin{array}{c}\text { Concentration } \\
\text { Polarization } \\
\left(\eta_{c}\right)\end{array}$ & $\begin{array}{c}\text { Activation }+ \\
\text { Concentration } \\
\text { Polarization } \\
\quad(\eta)\end{array}$ & $\begin{array}{c}\text { Electrode } \\
\text { Resistance } \\
(\text { Rct, } \Omega \text { ) }\end{array}$ & $\begin{array}{l}\text { Solution } \\
\text { Conductivity } \\
\text { at } 25{ }^{\circ} \mathrm{C} \\
(\mathrm{mS} / \mathrm{cm})\end{array}$ \\
\hline \multirow{6}{*}{$\begin{array}{c}\mathrm{Ir}+\mathrm{Sn}+\mathrm{Ta} \\
+\mathrm{Pd}\end{array}$} & 0 & 0.03 & 1.10 & 1.13 & 0.02 & 446.30 \\
\hline & 100 & 0.04 & 1.29 & 1.33 & 0.10 & 436.50 \\
\hline & 200 & 0.10 & 1.30 & 1.40 & 0.03 & 422.70 \\
\hline & 300 & 0.11 & 1.28 & 1.39 & 0.11 & 416.40 \\
\hline & 400 & 0.06 & 1.30 & 1.36 & 0.13 & 415.20 \\
\hline & 500 & 0.12 & 1.28 & 1.40 & 0.27 & 402.70 \\
\hline
\end{tabular}

Furthermore, in order to confirm the optimal conditions for zinc recovery according to the current density, the recovery time was fixed at $1 \mathrm{~h}$ and zinc recovery was performed using the current density as a variable. Using this electrolytic solution, the electrode resistance was measured during the oxidation of the insoluble catalyst electrode, including the effect of the substance diffusion (Figure 7a). As a result, it was confirmed that the electrode resistance was greatly increased due to the decrease of the electrode reaction area, as hydrogen gas was generated at the electrode surface when the current density was $100 \mathrm{~A} / \mathrm{m}^{2}$. Thereafter, the electrode resistance was greatly reduced when the current density was $200 \mathrm{~A} / \mathrm{m}^{2}$. In addition, the electrode resistance was continuously increased due to the decrease of the substance diffusion, which resulted from the decrease of the zinc concentration as the current density was increased to $300-500 \mathrm{~A} / \mathrm{m}^{2}$. 


\section{Conclusions}

- This study used an alumina (Al) anode, a lead electrode, and electrodes using an insoluble catalyst, which can increase the electrode stability and conductivity, as the cathode in order to increase the zinc recovery yield.

- The overpotential of the lead, three-component, and four-component electrodes were 0.49, 1.20 , and $1.13 \eta$, respectively, while the concentration polarizations were $0.40,1.16$, and $1.10 \eta_{\mathrm{c}}$. The overpotential was highly affected by the concentration polarization. A higher concentration polarization was found to generate a higher reduction in reactants, and thus the three- and four-component electrodes more actively recovered zinc compared to the lead electrode. Furthermore, the order of electrode resistance was the lead, the three-component, and the four-component electrodes.

- Using this sequence, the four-component electrode was identified as that with the greatest potential to lower the amount of required electrical energy due to its high reactivity for zinc recovery and low electrode resistance.

- At up to $3 \mathrm{~h}$ of zinc recovery time, the recovery yield was about $77 \%$ at the current density of $200 \mathrm{~A} / \mathrm{m}^{2}$, which was lower than that at a current density of $300 \mathrm{~A} / \mathrm{m}^{2}$ (recovery yield: about $80 \%$ ). After $3 \mathrm{~h}$ of recovery time, however, the electrode resistance (reaction surface resistance due to zinc recovery) and the increase in overpotential with time were lower at a current density of $200 \mathrm{~A} / \mathrm{m}^{2}$, significantly enhancing the zinc recovery yield to over $95 \%$.

- In conclusion, an increase in recovery yield is accompanied by a lower overpotential. As zinc recovery occurs on the electrode surface, the electrode with a smaller increase in activation polarization and resistance was determined to be more effective for zinc recovery.

Author Contributions: Conceptualization, J.-H.K. and E.S.L.; methodology, J.-H.K., J.E.P. and E.S.L.; software, J.-H.K.; validation, J.-H.K.; formal analysis, J.-H.K.; investigation, J.-H.K. and E.S.L.; resources, J.-H.K. and E.S.L.; data curation, J.-H.K., J.E.P. and E.S.L.; writing—original draft preparation, J.-H.K. and E.S.L.; writing一review and editing, J.-H.K.; supervision, E.S.L.; project administration, E.S.L.; funding acquisition, E.S.L.

Funding: This study was supported by the Energy Development Technology Program of the Korea Institute of Energy Technology Evaluation and Planning (KETEP) granted financial resources from the Ministry of Trade, Industry \& Energy, Republic of Korea (20172010105220) and also the National Research Foundation of Korea (NRF) and the Center for Women In Science, Engineering and Technology (WISET) Grant funded by the Ministry of Science and ICT under the Program for Returners into R\&D.

Conflicts of Interest: The authors declare no conflict of interest.

\section{References}

1. Lee, S.H.; Jo, Y.M. Review of national policies on the utilization of waste metal resources. KIC News 2010, 13, 2-9.

2. Frioui, S.; Oumeddour, R.; Lacour, S. Highly selective extraction of metal ions from dilute solutions by hybrid electrodialysis technology. Sep. Purif. Technol. 2017, 174, 264-274. [CrossRef]

3. Virolainen, S.; Ibana, D.; Raatero, E. Recovery of indium from indium tin oxide by solvent extraction. Hydrometallurgy 2011, 107, 56-61. [CrossRef]

4. Babilas, D.; Dydo, P. Selective zinc recovery from electroplating wastewaters by electrodialysis enhanced with complex formation. Sep. Purif. Technol. 2018, 192, 419-428. [CrossRef]

5. Lim, K.H.; Shon, B.H. Study on recovery of heavy metals from red mud by using the ultrasonic waves. J. Korea Acad. Industr. Coop. Soc. 2015, 16, 906-913. [CrossRef]

6. Kurama, H.; Goktepe, F. Recovery of zinc from waste material using hydrometallurgical processes. Environ. Prog. 2003, 22, 161-166. [CrossRef]

7. Modin, O.; Fuad, N.; Rauch, S. Microbial electrochemical recovery of zinc. Electrochim. Acta 2017, 248, 58-63. [CrossRef]

8. Cui, W.; Chen, Z.; Yu, Q.; Zhu, W.; Li, H.; Wang, H. Preparation of Ti/ $\mathrm{PbO}_{2}-\mathrm{ZrO}_{2}$ composite anode for $\mathrm{Zn}$ electrowining. Int. J. Electrochem. Sci. 2018, 13, 1400-1412. [CrossRef] 
9. Chen, G.; Chen, X.; Yue, P.L. Electrochemical behavior of novel Ti/IrOx-Sb $\mathrm{O}_{5}-\mathrm{SnO}_{2}$ anodes. J. Phys. Chem. B 2002, 106, 4364-4369. [CrossRef]

10. Kakooei, S.; Ismail, M.C.; Wahjoedi, B.A. Electrchemical study of Iridium oxide coating on stainless steel substrate. Int. J. Electrochem. Sci. 2013, 8, 3290-3301.

11. Wang, Y.; Xiao, S.; Cai, X.; Bao, W.; Reutt-Robey, J.; Fuhrer, M.S. Electronic transport properties of Ir-decorated graphene. Sci. Rep. 2015, 5, 15764-15770. [CrossRef] [PubMed]

12. Lin, J.J.; Huang, S.M.; Lin, Y.H.; Lee, T.C.; Liu, H.; Zhang, X.X.; Chen, R.S.; Huang, Y.S. Low temperature electrical transport properties of $\mathrm{RuO}_{2}$ and $\mathrm{IrO}_{2}$ single crystals. J. Phys. Condens. Matter 2004, 16, 8035-8041. [CrossRef]

13. Ryabtsev, S.V.; Levlev, V.M.; Samoylov, A.M.; Kuschev, S.B.; Soldatenko, S.A. Microsturcture and electrical properties of palladium oxide thin films for oxidizing gases detection. Thin Solid Films 2017, 636, 751-759. [CrossRef]

14. Park, J.E.; Yang, S.K.; Kim, J.H.; Park, M.J.; Lee, E.S. Electrocatalytic activity of Pd/Ir/Sn/Ta/TiO 2 composite electrodes. Energies 2018, 11, 3356. [CrossRef]

15. Jha, M.K.; Kumar, V.; Singh, R.J. Review of hydrometallurgical recovery of zinc from industrial wastes. Resour. Conserv. Recy. 2001, 33,1-22. [CrossRef]

16. Shinagawa, T.; Garcia-Esparza, A.T.; Takanabe, K. Insight on Tafel slopes from a microkinetic analysis of aqueous electrocatalysis for energy conversion. Sci. Rep. 2015, 5, 13801-13822. [CrossRef] [PubMed]

(C) 2019 by the authors. Licensee MDPI, Basel, Switzerland. This article is an open access article distributed under the terms and conditions of the Creative Commons Attribution (CC BY) license (http://creativecommons.org/licenses/by/4.0/). 